\title{
Role of Glutamic Acid Decarboxylase in the Prepubertal Inhibition of the Luteinizing Hormone Releasing Hormone Release in Female Rhesus Monkeys
}

\author{
Dai Mitsushima, ${ }^{1}$ Farshid Marzban, ${ }^{1}$ Laure L. Luchansky, ${ }^{1}$ Andrew J. Burich, ${ }^{1}$ Kim L. Keen, ${ }^{1}$ \\ Maureen Durning, ${ }^{1}$ Thaddeus G. Golos, ${ }^{1,3}$ and Ei Terasawa ${ }^{1,2}$ \\ ${ }^{1}$ Wisconsin Regional Primate Research Center, ${ }^{2}$ Center for Neuroscience, and ${ }^{3}$ Department of Obstetrics and \\ Gynecology, University of Wisconsin, Madison, Wisconsin 53715
}

To investigate further the role of GABA in the onset of puberty, this study examines whether glutamic acid decarboxylase (GAD), the catalytic enzyme for GABA synthesis, is involved in the suppression of luteinizing hormone releasing hormone $(\mathrm{LHRH})$ before puberty in rhesus monkeys. First, both GAD67 and GAD65 mRNAs were detectable by reverse transcriptionPCR analysis in the preoptic area, medio-basal hypothalamus, posterior hypothalamic area, and hippocampus of the monkey brain. Second, effects of antisense oligodeoxynucleotides (Doligos) for GAD67 and GAD65 mRNAs on LHRH release were examined in conscious female rhesus monkeys at the prepubertal stage using a push-pull perfusion method. The GAD67 or GAD65 antisense D-oligos or scrambled D-oligos were infused directly into the stalk-median eminence. Both the GAD67 and the GAD65 antisense D-oligos induced a large and prompt increase in LHRH release, whereas the scrambled D-oligos did not induce any significant effect. The results suggest that the removal of GABA inhibition by interfering with GAD synthesis is effective in increasing $\mathrm{LHRH}$ release in prepubertal monkeys. Third, the specificity of the antisense D-oligos on GAD levels was examined by incubating basal hypothalami with D-oligos in vitro and subsequent Western blot analysis. The antisense D-oligos consistently decreased the proteins GAD67 and GAD65 compared with respective control D-oligos. We conclude that the decrease of tonic GABAergic inhibition and maturational changes in GAD synthesis may be critical factors for the onset of puberty in nonhuman primates.

Key words: antisense oligodeoxynucleotide; GAD67; GAD65; GABA; LHRH; puberty
An increase in pulsatile release of luteinizing hormone releasing hormone (LHRH) is a critical factor for the onset of puberty in primates (Watanabe and Terasawa, 1989; Terasawa et al., 1990). Howcver, the underlying mechanism of the pubertal increase in LHRH release is unclear. It has been speculated that in primates there is a "central inhibition" of $\mathbf{L H}$ release and presumably LHRH release, starting a few months after the neonatal period and ending before the onset of puberty (Terasawa et al., 1983; Plant, 1988; Grumbach and Kaplan, 1990). LH and LHRH levels are low in juvenile monkeys, in which the negative feedback influence of gonadal steroids was removed during the neonatal period (Plant, 1983; Terasawa et al., 1983; Chongthammakun et al., 1993). Because LHRH neurons themselves appear to be mature well before the onset of puberty (Ronnekleiv and Resko, 1980; Silverman et al., 1982; Goldsmith and Song, 1987; Claypool et al., 1990; Vician et al., 1991), immaturity of the regulatory mechanisms

Received Nov. 13, 1995; revised Jan. 22, 1996; accepted Jan. 24, 1996.

This work (publication 35019 ) of the Wisconsin Regional Primate Research Center was supported by National Institutes of Health Grants RR00167, HD11355, and HD15433. We thank the Molecular Biology Core of the Wisconsin Regional Primate Research Center for RT-PCR and DNA sequencing, and the University of Wisconsin Biotechnology Center for synthesizing the oligonucleotides.

Correspondence should be addressed to Ei Terasawa, Wisconsin Regional Primate Research Center, 1223 Capitol Court, Madison, WI 53715.

Dr. Mitsushima's present address: Department of Physiology, Yokohama City University, School of Medicine, 3-9 Fukuura, Kanazawa-ku, Yokohama, Japan.

Dr. Marzban's present address: Department of Physiology, University of Kansas Medical Center, 39th and Rainbow Boulevard, Kansas City, KS 66103.

Copyright (C) 1996 Society for Neuroscience $0270-6474 / 96 / 162563-11 \$ 05.00 / 0$ for the LHRH neurosecretory system must be responsible for the low levels of LHRH release before the onset of puberty (Terasawa et al., 1990; Terasawa, 1995).

GABA is known as a dominant inhibitory ncurotransmittcr in the brain. Recently, we have proposed a hypothesis that GABA is an inhibitory neurotransmitter restricting LHRH release before the onset of puberty and that the removal of this inhibition is important for the pubertal increase in LHRH release (Mitsushima et al., 1994). This hypothesis was based on the following facts. (1) Direct infusion of the $\mathrm{GABA}_{\mathrm{A}}$ receptor blocker bicuculline into the stalk-median eminence (S-ME) dramatically stimulated LHRH release in prepubertal monkeys, whereas bicuculline stimulated LHRH release very little in pubertal monkeys. (2) Infusion of GABA into the S-ME of pubertal monkeys suppressed LHRH release, whereas it failed to cause any change in prepubertal monkeys. (3) GABA release in the S-ME in prepubertal monkeys was much higher than that in pubertal monkeys (Mitsushima et al., 1994).

Glutamic acid decarboxylase (GAD) is the enzyme catalyzing the synthesis of GABA from glutamate. Two subclasses of GAD have been described in the mammalian brain (Michelsen et al., 1991; Bu et al., 1992). The cDNAs encoding for human GAD67 and GAD65 have been cloned (Karlsen et al., 1991; Bu et al., 1992), and RNA blot hybridization with cDNA probes for human GADs has revealed that the brain of the rhesus monkey expresses both GAD mRNAs (Karlsen et al., 1991). It is plausible, therefore, that if synthesis of GADs is decreased by treatment with GAD-specific antisense oligodeoxynucleotides (D-oligos), it may 
alter the synthesis of GABA and, subsequently, LHRH release. In the present study, to investigate whether GADs are involved in the prepubertal suppression of LHRH release and to determine further the physiological role of GABA in the control of the onset of puberty, we have examined the effect of antisense D-oligos for GAD67 and GAD65 mRNAs on LHRH release in prepubertal monkeys.

\section{MATERIALS AND METHODS}

Animals

Ten prepubertal female rhesus monkeys (Macaca mulatta) ranging from 13 to 20 months of age were used in push-pull perfusion studies. The monkeys were weaned at 10-11 months of age and housed in rooms with controlled lighting of $12 \mathrm{hr}$ light (lights on 6:00 A.M.) and $12 \mathrm{hr}$ darkness and a controlled temperature $\left(22^{\circ} \mathrm{C}\right)$. Monkeys were fed a standard diet of Purina monkey chow daily, supplemented with fresh fruits several times per week. Tap water was available ad libitum.

\section{Implantation of cranial pedestal}

Monkeys were implanted with a cranial pedestal under halothane anesthesia as described previously (Gearing and Terasawa, 1988; Terasawa, 1994). During the surgery, a radio-opaque dye was injected into the foramen of Monro to visualize the third ventricle, and $\mathrm{x}$-ray pictures were taken to allow accurate positioning of the cannula in the S-ME in later experiments. Animals were allowed to recover at least 1 month before the initiation of experiments. During this period, monkeys were well adapted to the primate chair, the experimental environment, and investigator before the initiation of the experiments.

\section{Push-pull perfusion}

Two to three days before a push-pull perfusion experiment, a monkey under ketamine/xylazine anesthesia was placed in a stereotaxic apparatus for cannula implantation. An outer cannula with stylet was inserted into the S-ME using a microdrive unit (MO95-B, Narishige, Tokyo, Japan), and cannula placement was compared to ventriculograms taken during pedestal implantation as described previously (Gearing and Terasawa, 1988; Terasawa, 1994). The monkeys were placed in a primate chair. On the day of the experiment, the stylet was replaced with an inner cannula (29 gauge) through which a modified Krebs-Ringer phosphate buffer solution was infused at $23.5 \mu \mathrm{l} / \mathrm{min}$ via a peristatic pump (Minipulse3, Gilson Medical Electric, Middleton, WI). Perfusates were collected continuously in $10 \mathrm{~min}$ fractions on ice from the outer cannula using an identically calibrated pump. Volumes of 150 and $\sim 85 \mu \mathrm{l}$ were aliquoted for radioimmunoassay (RIA) of LHRH and later HPLC analysis of $\mathrm{GABA}$, respectively. Samples were snap-frozen and stored at $-70^{\circ} \mathrm{C}$ until assay.

\section{Experimental design}

Experiment 1. To determine whether the rhesus monkey brain contains GAD67 and GAD65 mRNAs, RNA from the preoptic area, medio-basal hypothalamus with median eminence, posterior hypothalamic area, and hippocampus was isolated from two adult rhesus monkey brains. The brain tissues of the rhesus monkeys were obtained through the Tissue Distribution Program of the Wisconsin Regional Primate Research Center. For negative controls, RNA from the liver of a monkey fetus and the placenta of a female monkey at day 73 of gestation was also obtained. RNA samples were analyzed for GAD67 and GAD65 mRNAs by reverse transcription (RT)-PCR. For reverse transcriptases, $10 \mu \mathrm{g}$ of total RNA was denatured in water at $70^{\circ} \mathrm{C}$ for $10 \mathrm{~min}$, added to a $20 \mu \mathrm{l}$ (final volume) reaction containing $50 \mathrm{~mm}$ Tris- $\mathrm{HCl}, \mathrm{pH} 8.3,75 \mathrm{~mm} \mathrm{KCl}, 3 \mathrm{~mm} \mathrm{MgCl} 2,1$ $\mathrm{U}$ of Inhibit-ace ribonuclease inhibitor (5 Prime-3 Prime, Boulder, CO), $100 \mathrm{ng}$ of an oligo(dT) primer (GACTCGAGTCGACATCGAT ${ }_{17}$ ), and $0.125 \mathrm{~mm}$ each deoxynucleotide triphosphate and $100 \mathrm{U}$ of Superscript reverse transcriptase (Gibco, Gaithersburg, MD), and incubated at $37^{\circ} \mathrm{C}$ for $1 \mathrm{hr}$. One to twenty microliters of reverse transcriptase of the reaction was then subjected to PCR. The PCR primers for GAD67 and GAD65 mRNAs were based on sequences common to human and rat mRNAs and amplified a 211 bp cDNA and a 382 bp cDNA for GAD67 and GAD65, respectively. The primers for glyceraldehyde 3-phosphate dehydrogenase (G3PDH) amplified a 980 bp cDNA as described previously (Golos et al., 1993). The PCR primers were synthesized by the University of Wisconsin Biotechnology Center. The aliquot of the RT reaction was added to $12.5 \mathrm{pmol}$ each of GAD or G3PDH primer, $0.25 \mathrm{~mm} d$-NTPs (Pharmacia, Piscataway, NJ), and $1 \times$ AmpliTaq buffer in which final reaction concentrations were $10 \mathrm{~mm}$ Tris, pH-adjusted to 8.3 with $50 \mathrm{~mm}$ $\mathrm{KCl}, 1.5 \mathrm{~mm} \mathrm{MgCl}_{2}, 0.001 \%(\mathrm{w} / \mathrm{v})$ gelatin, $15 \%$ glycerol $(10 \%$ for G3PDH), and $1.25 \mathrm{U}$ of AmpliTaq (Perkin-Elmer, Oak Brook, IL) in a
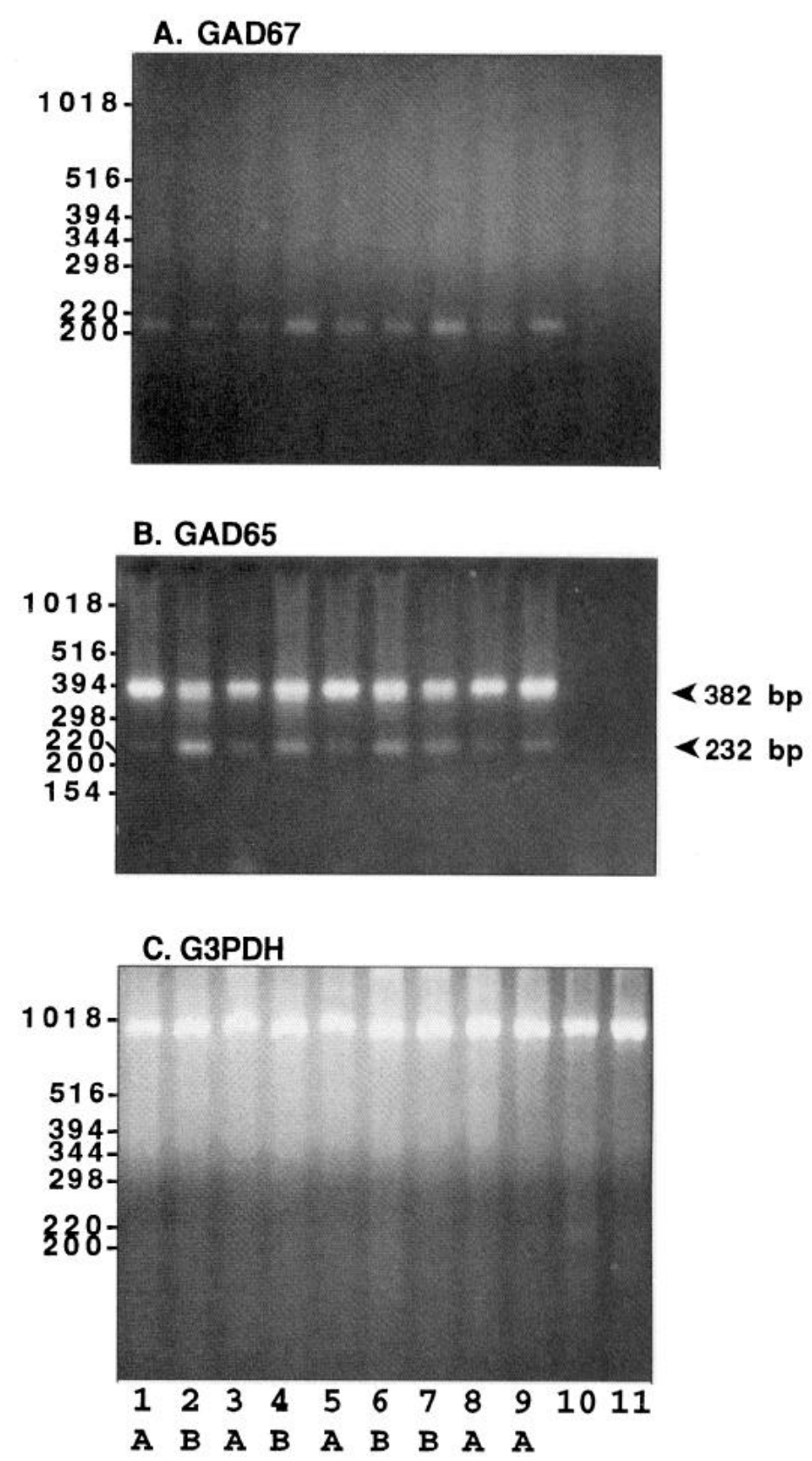

Figure 1. RT-PCR analysis of rhesus monkey brain mRNAs for GAD67 $(A)$ and GAD65 $(B)$. Two micrograms of total RNA from each brain sample shown, as well as fetal liver and midpregnancy placenta (negative controls for GAD mRNAs), were reverse-transcribed, and $4.5 \mu \mathrm{l}$ of RT reactions was subjected to PCR amplification with the indicated primers. Amplification products $(25 \mu \mathrm{l}$ for GAD67, $40 \mu \mathrm{l}$ for GAD65) were fractionated through $3.0 \%$ agarose gels. DNA size markers are indicated at the left, and tissue samples are labeled across the bottom. 1, Medio-basal hypothalamus; 2,3 , posterior hypothalamus; 4,5 , preoptic area; $6-9$, hippocampus; 10, fetal liver; 11, placenta. The same alphabet letter indicates that tissues were obtained from the same monkey. Amplification for G3PDH $(C)$ is shown to verify RNA integrity. Because the amount of PCR product in the initial GAD65 amplification was quite low, $B$ presents amplification product from a second round of PCR, using $0.1 \mu \mathrm{l}$ of the first-round reaction as template. 
total volume of $50 \mu \mathrm{l}$. The first cycle consisted of $1 \mathrm{~min}$ at $94^{\circ} \mathrm{C}, 30 \mathrm{sec}$ at $55^{\circ} \mathrm{C}$, and $1 \mathrm{~min}$ at $72^{\circ} \mathrm{C}$. In subsequent cycles, the $94^{\circ} \mathrm{C}$ step was held for $30 \mathrm{sec}$. A total of 35 cycles was run. Samples were held at $72^{\circ} \mathrm{C}$ for $7 \mathrm{~min}$ after completion of the final amplification cycle. After amplification, $25 \mu \mathrm{l}$ aliquots of the PCR reactions were fractionated in 3\% Nusieve (FMC Bioproducts, Rockland, ME) agarose gels ( $1 \times$ TBE running buffer $)$, and DN $\wedge$ bands were visualized by ethidium bromide staining. Becausc the amount of PCR product for GAD65 was consistently lower than that of GAD67 in the first PCR reaction, a second round of 35 PCR cycles was carried out for GAD65 with $0.1 \mu \mathrm{l}$ of the first PCR reaction as template, and $40 \mu \mathrm{l}$ of the second reaction was loaded for visualization.

Experiments 2 and 3. To examine whether GADs are involved in the suppression of LHRH release before the onset of puberty, the effects of antisense D-oligos for GAD67 mRNA or for GAD65 mRNA on LHRH release were examined in conscious prepubertal female monkeys using a push-pull perfusion method. For antisense D-oligos, 20-mer oligodeoxynucleotides that corresponded to the GAD enzyme $\mathrm{N}$ terminus immediately downstream from the initiation codon were used. For controls, oligonucleotides with scrambled sequences of the respective antisense D-oligos were used.

The sequences of the oligonuclcotides were as follows:

GAD67 antisense D-oligo: 5'-GAAGATGGGGTCGAAGACGC-3' GAD67 scrambled D-oligo: 5'-TAGGAGCAGACTGAGAGGCG-3' GAD65 antisense D-oligo: 5'-AAGCCAGAGCCCGGAGATGC-3' GAD65 scrambled D-oligo: 5'-CGGCACGTCAACGGAAGAGC-3'

After a $3 \mathrm{hr}$ control perfusion, an antisense or scrambled D-oligo for either GAD67 mRNA or GAD65 mRNA at $10^{-6} \mathrm{M}$ in a modified Krebs-Ringer phosphate buffer was continuously infused for 6 hr. Perfusion was continued for an additional 5-6 hr. Of 10 monkeys, 4 were exclusively used for experiment 2 (GAD67), 3 were exclusively for experinlent 3 (GAD65), and the remaining 3 were for both studies. Between perfusion experiments, the monkey was rested in her home cage for at least 1 month.
Experiment 4. Specificity of the antisense D-oligos for GAD67 and GAD65 mRNAs was examined by exposing brain tissues to the D-oligos for either GAD67 mRNA or GAD65 mRNA in vitro and subsequent Western blot analysis for respective enzyme proteins. The cerebellum and the hypothalamus of the rhesus monkeys were obtained through the Tissue Distribution Program of the Wisconsin Regional Primate Research Center. The basal hypothalamus was dissected out on ice caudal to the optic chiasm anteriorly, posterior to the mamillary body caudally, at the infundibular sulcus laterally, and $3 \mathrm{~mm}$ above the base of the brain dorsally, and was bisected further at the midline. The cerebellar cortex from the superior hemisphere of both sides was dissected out and cut into four small pieces of similar size on ice. Each tissue was then placed in a small perifusion chamber and perifused with medium consisting of $50 \%$ artificial CSF (Gearing and Terasawa, 1988) and 50\% M199 (Gibco) under $95 \% \mathrm{O}_{2} / 5 \% \mathrm{CO}_{2}$ at $37^{\circ} \mathrm{C}$ at a rate of $6 \mu \mathrm{l} / \mathrm{min}$ using a perifusion system (Endotronics, Minneapolis, $\mathrm{MN}$ ).

After $1 \mathrm{hr}$ of control perifusion, hypothalamic tissues were continuously cxposed to either the antisense D-oligos or the scrambled D-oligos at a concentration of $10^{-6} \mathrm{M}$ for a $6 \mathrm{hr}$ period. Similarly, three cerebellar tissues were each exposed to antisense D-oligos, scrambled D-oligos, or sense D-oligos. The remaining cerebellar tissue was not exposed to any D-oligos as a control. After completion of the perifusion, the tissues were removed from the chambers, quickly weighed, and homogenized in buffer at a concentration of $10 \mathrm{mg} / \mu \mathrm{l}$ tissue weight. Homogenates were then centrifuged $(15,000 \times g)$ at $0^{\circ} \mathrm{C}$ and supernatants were obtained, aliquoted, and stored at $-70^{\circ} \mathrm{C}$ until Western blot analysis.

Samples adjusted to contain the same concentration of protein were denatured at $95^{\circ} \mathrm{C}$ in a loading buffer containing SDS (final concentration $2 \%$ ) and $\beta$-mercaptoethanol (final concentration $2 \%$ ) and subjected to SDS-PAGE $(10 \%)$. Fractionated proteins were then electroblotted (Hoefer Scientific Instruments) onto polyvinylidene fluoride membrane (Millipore, Bedford, MA).

A monoclonal antibody for GAD65 immunodetection was obtained from the Hybridoma Bank (Iowa City, IA), and a polyclonal antibody for

RHESUS GAD67 CDNA

578 GCAACCTCCTCGAACGCGGGAGCGGACCCCAATACCACTAACCTGCGCCCCACAACGTACGATACCTGGTGCGGCGTGGCCCATGGATGCACCAGA

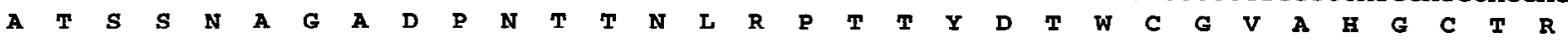

674 AAATGGGGCTCAAGATCTGCGGCTTCTTGCAGAGGACCAACAGCCTGGAAGAGAAGAGTCGCCTTGTGAGTGCCTTCAAGGAGAGGCAGTCCTCC

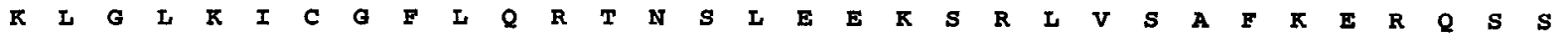
A

(R)

770 AAGAACCTGCTTTCCTGTGA K $N$ I $L \quad S \quad C$

\section{RHESUS GAD65 CDNA}

146 CATCTCCGGGCTCTGGCTTTTGGTCCTTCGGGTCGGAAATGGCTCCGGGGATTCCGACAATCCCGGCACAGCGCGAGCCTGGTGCCAAGTGGCTC

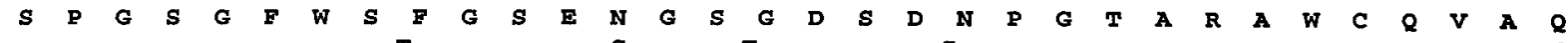
(D) $\quad$ (E)

242 AGAAGTTCACGgGCGGCATCGGAAACAAACTGTG GCCCTGCTCTACGGAGACGCCGAGAAGCCGGCGGAGAGCGGCGGGAGCCAACCCCCGCGGG

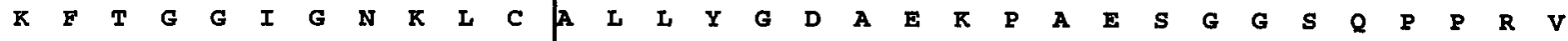

338 TCGCCGCCCGGAAGGCCGCCTGCGCCTGCGACCAGAAGCCCTGCAGCTGTCCCAAAGCGGATGTCAACTACGGGTTTCTCCATGCAACA GACCTGC

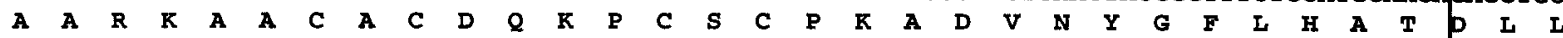

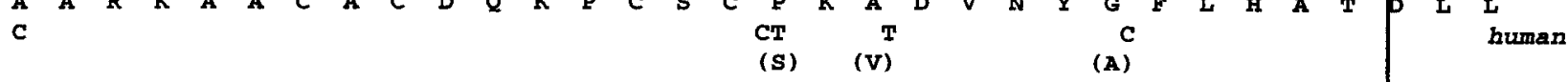

434 TGCCGGCGTGTGATGAGAAAGGCCACTTPGGGTTTCTGCAAGATGTTATGAACATTTACTTCAGTATGTGGMGAAAGTTCGATAGATC $\begin{array}{llllllllllllllllllllllllllllll}\mathbf{P} & \mathbf{A} & \mathbf{C} & \mathbf{D} & \mathbf{G} & \mathbf{E} & \mathbf{R} & \mathbf{P} & \mathbf{T} & \mathbf{L} & \mathbf{A} & \mathbf{F} & \mathbf{L} & \boldsymbol{Q} & \mathbf{D} & \mathbf{V} & \mathbf{M} & \mathbf{N} & \mathbf{I} & \mathbf{L} & \mathbf{L} & \mathbf{Q} & \mathbf{Y} & \mathbf{V} & \mathbf{V} & \mathbf{K} & \mathbf{S} & \mathbf{F} & \mathbf{D} & \mathbf{R}\end{array}$

Figure 2. Partial nucleotide and predicted protein sequences of GAD67 and GAD65 in rhesus monkeys. The 211 bp cDNA from GAD67 and 382 and 232 bp cDNAs from GAD65 PCR reactions were isolated from agarose gels, subcloned, and sequenced. The sequences of the cDNAs appear above the predicted amino acid sequences, and are numbered according to the full-length human mRNAs. The nucleotide sequences and deduced amino acid sequences of the cloned rhesus monkey fragments appear in full. Nucleotides of the human mRNAs that differ from those of the rhesus monkey are shown below the rhesus protein sequences, and amino acids that differ from the rhesus protein are shown in parentheses. The boxed region in the GAD65 clone represents sequences not present in the $232 \mathrm{bp} \mathrm{PCR} \mathrm{amplification} \mathrm{product,} \mathrm{which} \mathrm{results} \mathrm{in} \mathrm{an} \mathrm{in-frame} \mathrm{deletion} \mathrm{of} 50$ amino acids. 
GAD67 immunodetection was obtained from Biogenesis (Sandown, NH). Antibodies were used at dilutions of 1:160 and 1:8000, respectively. For the second antibodies, goat anti-mouse and goat anti-rabbit, respectively, conjugated with alkaline phosphatase were used. Finally, the substrate 5-bromo-4-chloro-3-indolyl phosphate and chromagen $p$-nitroblue tetrazolium chloride were applied to the membrane.

\section{Assays}

LHRH in perfusates was measured by RIA using antiserum R1245, kindly provided by Dr. T. Nett (Rasmussen et al., 1988), as described previously (Gearing and Terasawa, 1988; Watanabe and Terasawa, 1989). Synthetic LHRI (Richelieu Laboratory, Montréal, Québec, Canada) was used for the radiolabeled antigen and reference standard. Sensitivity of the assay was $0.1 \mathrm{pg} /$ tube. In the present report, the data on the release of GABA are not included because the assay has not been completed.

\section{Statistics}

To determine the effects of infusion of D-oligos on LHRH release, mean LHRH levels during each hour before the D-oligos infusion were compared with mean LHRH levels during each hour after the infusion using two-way ANOVA with repeated measures in which variables were $\mathrm{D}$-oligos and time. To determine the specific time of the effects of D-oligo on LHRH release, data were analyzed further by Student-Newman-
Keuls multiple-range test. Significance was attaincd at $p<0.05$. For graphic expression, normalized data are used: in each animal, the mean LHRH level in the $3 \mathrm{hr}$ before the D-oligo infusion was designated as $100 \%$, and the mean LHRH levels in each hour before and after the initiation of D-oligos were calculated relative to the preinfusion mean.

All experiments presented in this manuscript were performed following the standards established by the Animal Welfare Act and Principles for Use of Animals and Guide for the Care and Use of Laboratory Animals. The protocol for this study was reviewed and approved by the Research Animal Resource Center, University of Wisconsin.

\section{RESULTS}

\section{GAD mRNAs in the monkey brain (experiment 1)}

Samples of total RNA isolated from various brain regions, liver, and placenta were subjected to RT-PCR analysis for GAD67 and GAD65 mRNAs. Figure $1 A$ illustrates that a single band of 211 bp for GAD67 was present in all brain samples, but not in the liver or placenta. Figure $1 B$ demonstrates specific amplification from the same $\mathrm{RT}$ reactions of the expected cDNA of 382 bp for GAD65, and an additional band of $\sim 232$ bp. All bands were subcloned and sequenced, and the 211 and
Figure 3. Effects of an antisense oligodeoxynucleotide for the GAD67 mRNA (GAD67AS) on LHRH release in the S-ME of two conscious prepubertal female rhesus monkeys. Note that the LHRH release started to increase 3-4 hr after the initiation of GAD67AS infusion, and the increase returned to control levels $1-2 \mathrm{hr}$ after the termination of infusion.
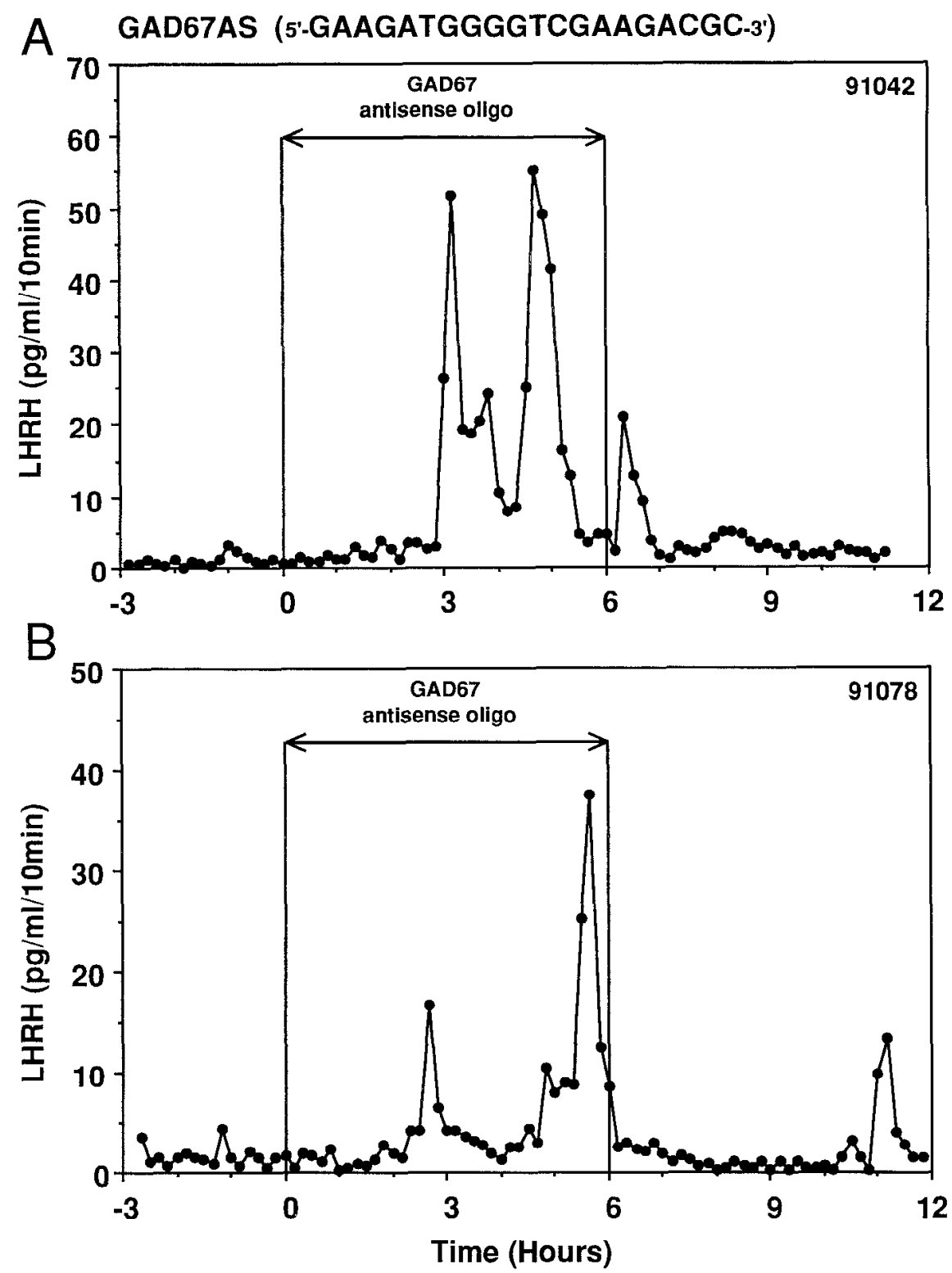
382 bp bands represented the expected cDNAs for GAD67 and GAD65, respectively. The relative amounts of GAD65 amplification product were consistently lower than those of GAD67 in all brain samples (data not shown). Figure $1 C$ shows abundant amplification product from all samples for the control mRNA G3PDH; no bands were obtained in the absence of reverse transcriptase or input RNA (data not shown).

Two bands were seen in PCR amplifications with primers specific for the GAD65 mRNA (Fig. $1 B$ ). When both fragments were subcloned and sequenced, they were found to represent authentic GAD65 cDNAs, but the smaller fragment of 232 bp had a deletion of $150 \mathrm{bp}$ (Fig. 2), which would result in a predicted protein lacking amino acids $46-95$ of the human protein.

\section{Effects of an antisense D-oligo for GAD67 mRNA on LHRH release (experiment 2)}

Before the $\mathrm{D}$-oligo infusion, LHRH levels in prepubertal monkeys were very low, as were typical at this stage (Figs. 3, 4). Infusion of antisense D-oligo to GAD67 $\left(10^{-6} \mathrm{M}\right)$ into the S-ME resulted in a drastic increase in LHRH release starting 3-4 hr after the initiation of the infusion. Commonly, this increase lasted for $\sim 1-2 \mathrm{hr}$ after the cessation of the antisense infusion (Fig. $3 A$ ), but in some cases a residual effect was observed several hours after the cessation of the infusion (Fig. 3B). In contrast, scrambled D-oligo to GAD67 infusion did not cause any significant effects on LHRH release (Fig. 4). Statistical analysis indicated that antisense D-oligo to GAD67 $\left(10^{-6} \mathrm{M}\right)$ induced a significant effect on LHRH release $(p<0.001)$. Post hoc analysis further revealed that a significant increase in LHRH release occurred from the third hour of initiation of antisense D-oligo to GAD67 infusion until $1 \mathrm{hr}$ after the cessation of the infusion compared both with preinfusion levels and with levels of the corresponding periods after infusion of scrambled D-oligo to GAD67 (Fig. 5).

\section{Effects of an antisense D-oligo for GAD65 mRNA on LHRH release (experiment 3 )}

Infusion of antisense D-oligo to GAD65 $\left(10^{-6} \mathrm{M}\right)$ also induced an increase in LHRH release (Fig. 6), whereas infusion of scrambled
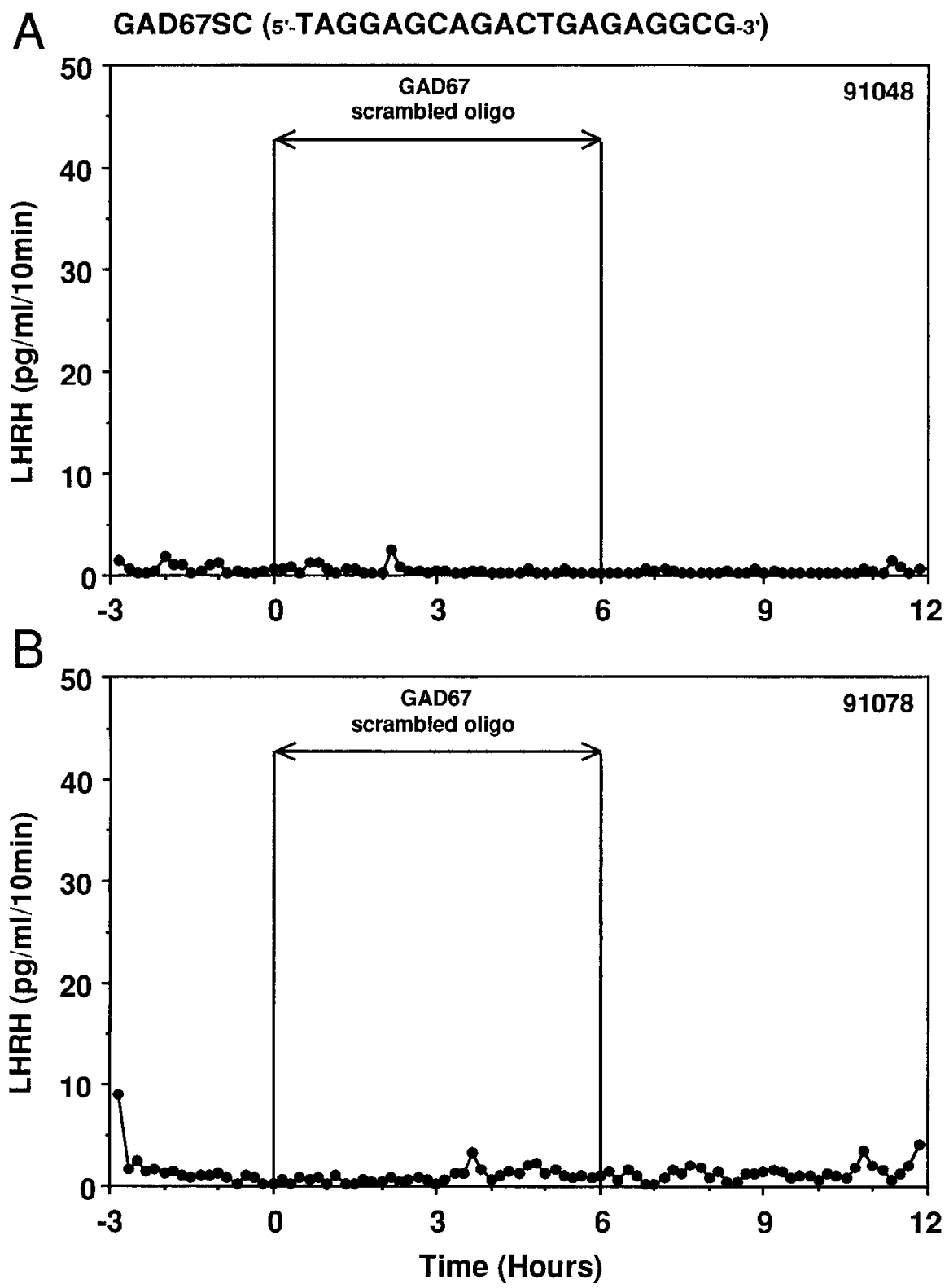

Figure 4. Effccts of a scrambled oligodeoxynucleotide for GAD67 mRNA (GAD67SC) on LHRH release in the S-ME of two conscious prepubertal female rhesus monkeys. Case $B$ is the control from the same monkey shown in Figure 3. Note that no changes were observed throughout the experiment in these as well as other cases not shown. 
A

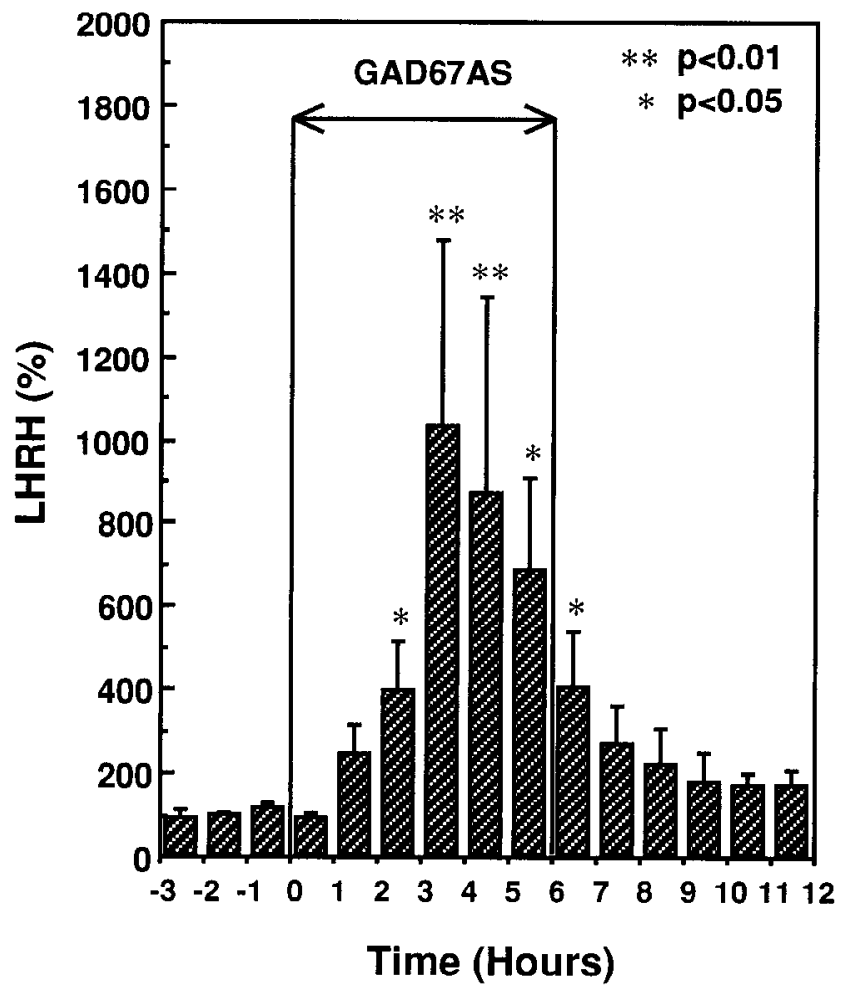

$\mathrm{B}$

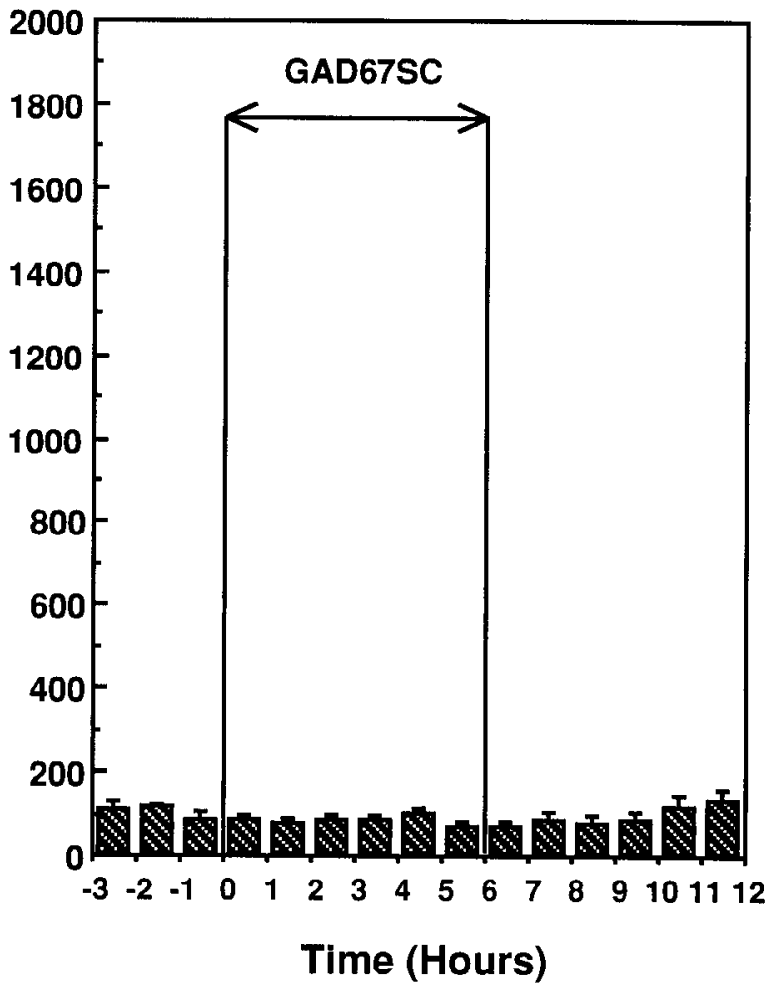

Figure 5. Effects of GAD67AS $(A)$ or GAD67SC $(B)$ on mean LHRH release in prepubertal monkeys. Mean LHRH release was calculated for each 60 min period. Data were analyzed using ANOVA with repeated measures followed by Student-Newman-Keuls multiple-range test (mean \pm SEM, $n=6$ in $G A D 67 A S, n=4$ in $\left.G A D 67 S C ;{ }^{* *} p<0.01 ;{ }^{*} p<0.05\right)$. Overall significance between two treatments was $p<0.001$.

D-oligo to GAD65 did not cause any significant effects (Fig. 7). ANOVA indicated that the effect of antisense D-oligo to GAD65 was significant from that of scrambled D-oligo $(p<0.01)$. Post hoc analysis revealed that the increase in LHRH release from hours 2 , 3 , and 5 of the antisense D-oligo to GAD65 infusion was significantly greater than preinfusion levels or levels of the corresponding periods after infusion of scrambled D-oligo to GAD65 (Fig. 8), and a significant increase was also observed from the 1st to 6 th hour after the cessation of the GAD65 antisense infusion compared with preinfusion levels.

Interestingly, the maximum increase during the exposure to antisense GAD67 D-oligo (Fig. 3) was larger than that during antisense GAD65 D-oligo infusion (Fig. 6).

\section{Effects of antisense D-oligos on behaviors}

Because GABA is involved in various physiological functions, we have made careful observations on behavioral changes during and after infusion of D-oligos. Although infusion of antisense D-oligo to GAD67 appcarcd to increase food intake very slightly, a quantitative analysis was not conducted. No other typical changes in behavior were observed with antisense D-oligo to GAD67. The infusion of antisense D-oligo to GAD65 induced epileptic seizure in one of the four monkeys, and another one had some symptoms of epilepsy several hours after the termination of sample collection, when the animals were already returned to their home cages. The remaining two monkeys did not exhibit any significant behavioral changes.

\section{Specificity of the antisense D-oligos for GAD67 and GAD65 mRNAs (experiment 4)}

The expression of GAD67 in the hypothalamic sample exposed to the antisense D-oligo for GAD67 mRNA was modestly but consistently lower than that in the sample exposed to the scrambled D-oligo (Fig. 9). Similarly, the expression of GAD67 in the cerebellar sample exposed to the antisense D-oligo was lower than that in the samples exposed to the scramblcd D-oligo for GAD67 mRNA, the sense D-oligo for GAD67 mRNA or the control (Fig. 9). Very similar results were seen for GAD65 expression in both tissues, i.e., expression of GAD65 in tissues exposed to the antisense D-oligo for GAD65 mRNA was less than that in tissues exposed to the scrambled or sense D-oligos for GAD65 mRNA (Fig. 9).

\section{DISCUSSION}

The findings of the present study are summarized as follows. First, we have found that both GAD67 and GAD65 mRNAs and their proteins are present in the rhesus monkey brain. Second, direct infusion of the GAD67 antisense into the S-ME dramatically stimulated the release of LHRH, whereas the GAD67 scrambled did not. Third, the GAD65 antisense also enhanced the release of LHRH, whereas the GAD65 scrambled did not. Finally, the antisense D-oligos specifically decreased expression of the proteins GAD67 and GAD65.

Human cDNAs for both forms of GADs have been isolated and sequenced from the brain (Karlsen et al., 1991; Bu et al., 1992). 

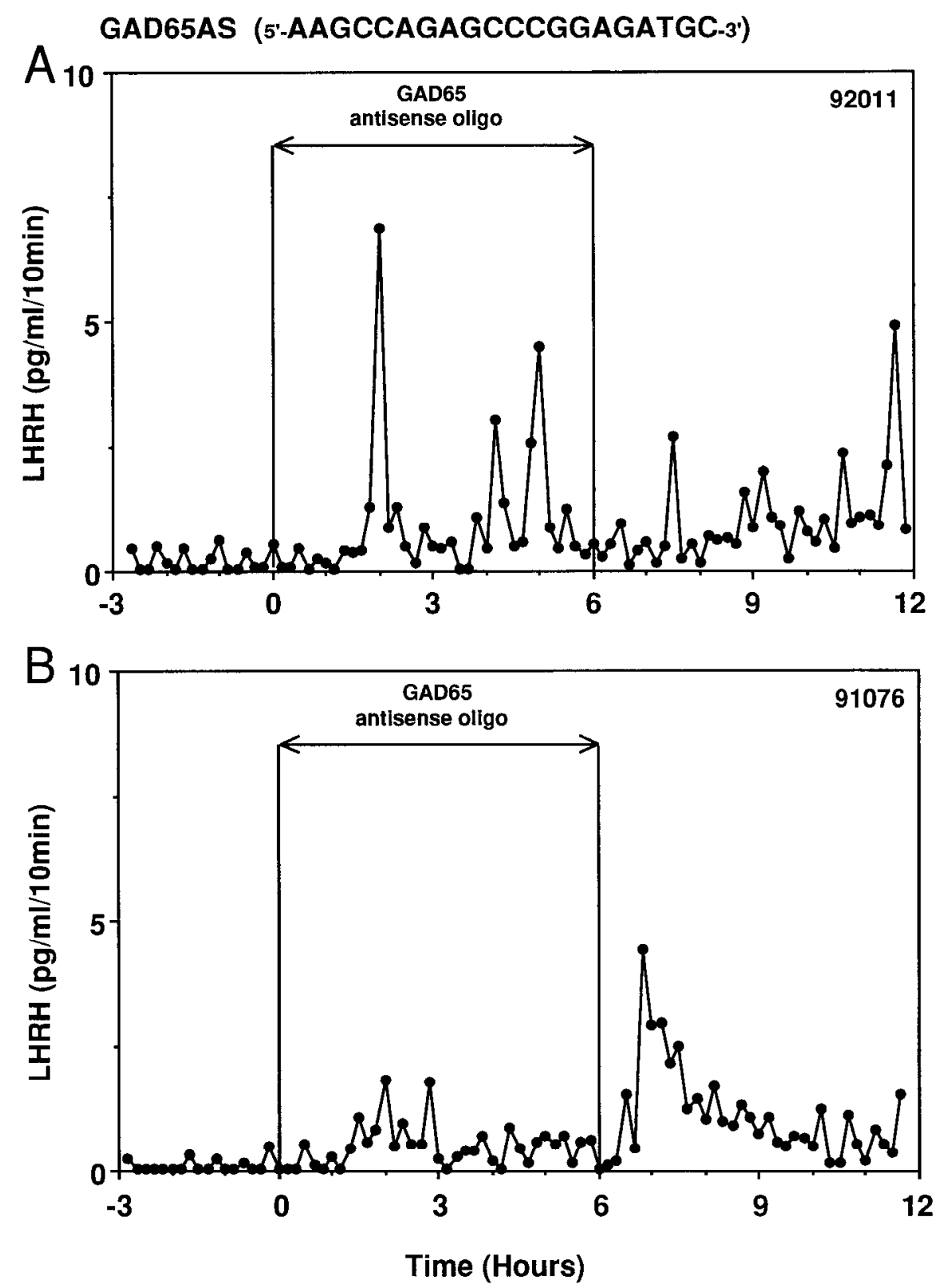

Figure 6. Effects of an antisense oligodeoxynucleotide for GAD65 mRNA (GAD65AS) on LHRH release in the S-ME of two conscious prepubertal female thesus monkeys. Note that LHRH started to increase 2-3 hr after the initiation of GAD65AS infusion, and the increase lasted for several hours after the termination of infusion. However, the increased levels of LHRH were not as large as those observed with GAD67AS.
The presence of both forms of GAD mRNAs in the monkey brain was also reported using Northern blot analysis (Karlsen et al., 1991) and in situ hybridization (Benson et al., 1991). Our RT-PCR results are consistent with those findings. Moreover, the fact that the GAD65 mRNA in the hypothalamus and hippocampus is less abundant than GAD67 mRNA suggests that GAD67 may be a dominant enzyme for GABA synthesis in these areas of the monkey brain.

In the present study, although the 382 bp fragment represented the previously cloned GAD65 cDNA, the 232 bp fragment had a novel deletion of $150 \mathrm{bp}$, which would result in a predicted protein lacking amino acids $46-95$ (see Fig. 2). To our knowledge, the gene coding for the GAD65 mRNA has not been sequenced in any species; thus, it is unclear whether the bands represent alternatively spliced mRNAs or products of separate genes. However, the fact that all brain tissues obtained from two monkeys expressed both fragments suggests that this may be characteristic of the GAD65 mRNA popula- tion in the brain. The functional significance of these results remains to be determined.

It has been speculated that both unmodified (D-) and phosphorothioate-substituted oligonucleotides enter the cells via a receptor-mediated endocytosis with mechanisms yet to be identified, or by passive diffusion (Loke et al., 1989; Kregenow et al., 1995). Moreover, the uptake of D-oligo is relatively quicker than that of phosphorothioate-substituted oligo (Woolf et al., 1992; Legrand et al., 1993). Antisense D-oligos can interfere with protein synthesis by mechanisms such as arresting mRNA hybridization mechanically (Helene and Toulme, 1990; Kregenow et al., 1995 ) or the cleavage of mRNA with ribonuclease $H$ (Walder and Walder, 1988; Woolf et al., 1992). The observation that the LHRH increase occurs consistently $2-3 \mathrm{hr}$ after the initiation of the antisense infusion suggests that the uptake of the antisense oligonucleotide and inhibition of GAD protein synthesis occurs in a relatively short time course. However, it is unclear whether the prolonged effects of the antisense GAD65 on LHRH release are 


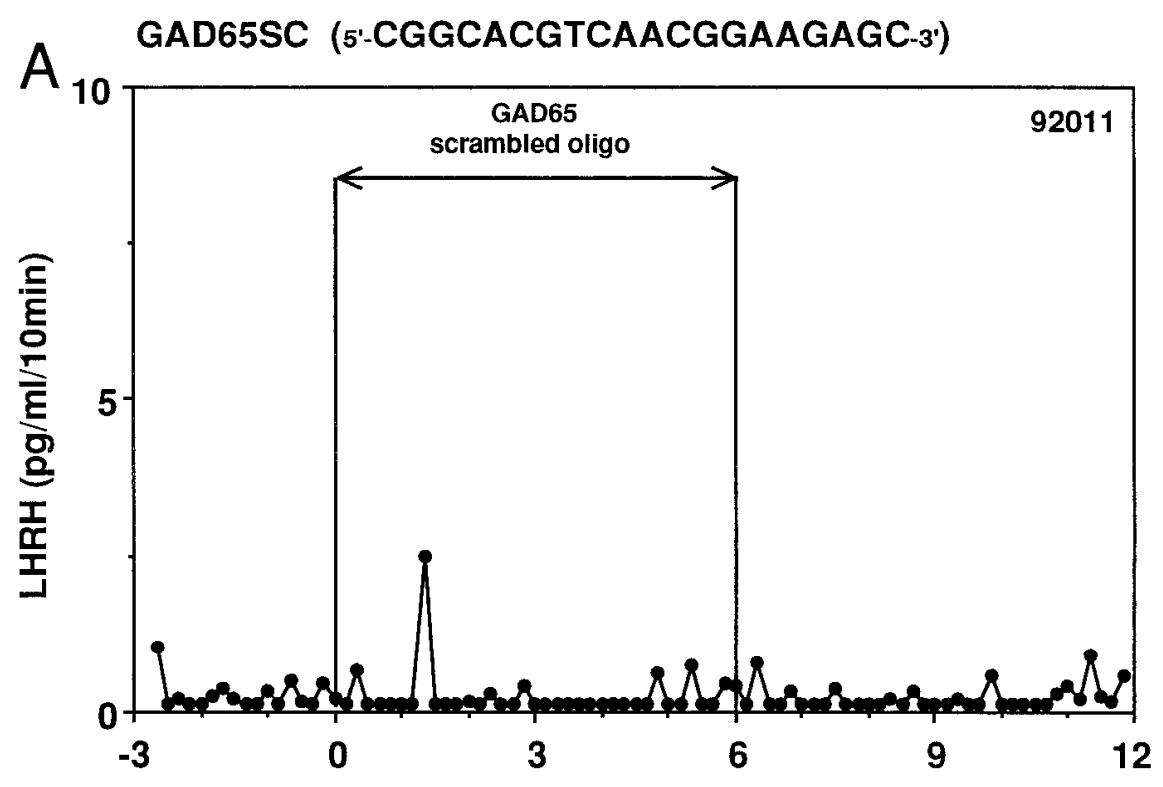

Figure 7. Effects of scrambled oligodeoxynucleotide for GAD65 mRNA (GAD65SC) on LHRH release in the $\mathrm{S}-\mathrm{ME}$ of two conscious prepubertal female rhesus monkeys. Both cases are controls for experiments shown in Figure 6. Note that no apparent changes were observed throughout the experiment.

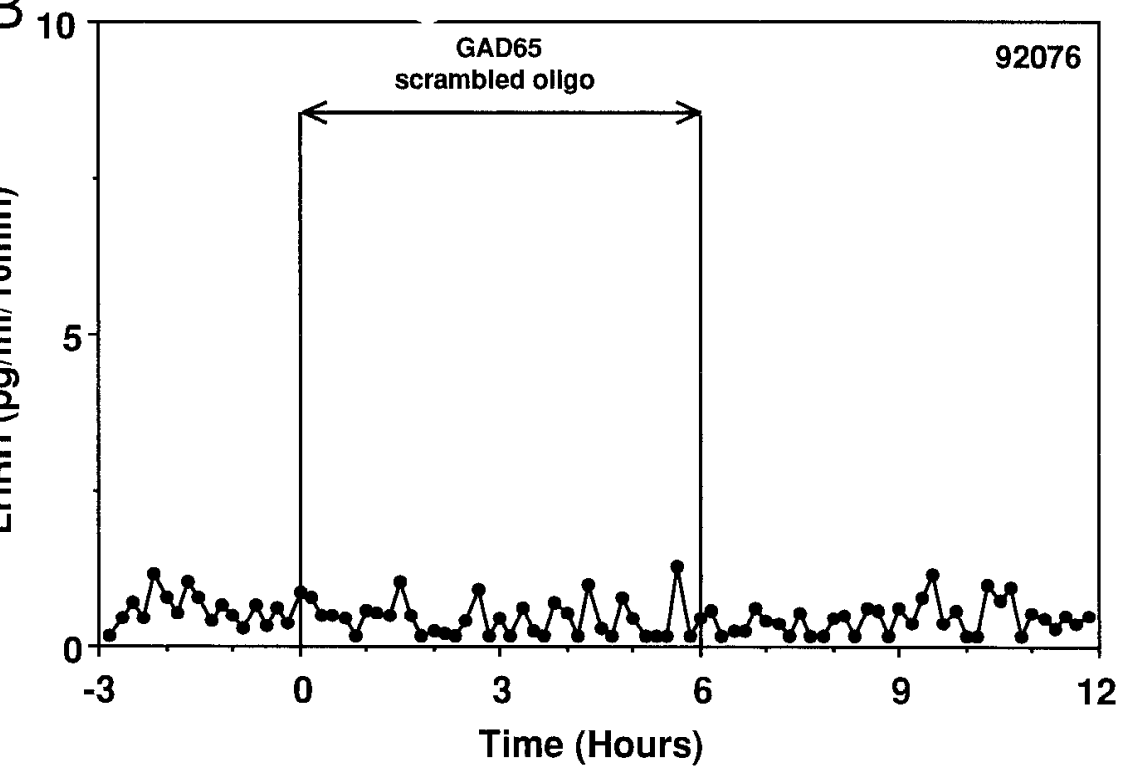

related to the longer half-life $(20-30 \mathrm{hr})$ of GAD65 than that of GAD67 (<4 hr) (Christgau et al., 1991), to a difference in subcellular distribution of the two enzymes (Esclapez et al., 1994), or to a difference in GAD65 and GAD67 syntheses (Martin and Rimvall, 1993). It is possible that intracellular GAD67 levels may recover quickly after the cessation of antisense GAD67 infusion, whereas GAD65 levels may stay low after the antisense GAD65 because, unlike GAD65 protein levels, GAD67 protein levels are sensitive to small increases in intracellular GABA levels (Rimvall and Martin, 1994).

Incubation of hypothalamic tissue and cerebellar cortex with antisense D-oligo decreased expression of both GAD67 and GAD65 (Fig. 9) compared with those incubated with scrambled or sense D-oligos. These findings, together with preliminary data showing a reduction in in vivo release of GABA in the S-ME by antisense D-oligos (E. Terasawa, unpublished data), suggest that the antisense D-oligos for GAD mRNAs infused into the S-ME were specific in their interference with GAD synthesis. The inhi- bition of protein synthesis by antisense oligonucleotides has been reported for LH receptors (West and Cooke, 1991), neuropeptide Y (NPY) receptors (Wahlestedt ct al., 1993), estrogen and progesterone receptors (McCarthy et al., 1993; Ogawa et al., 1994), GADs (McCarthy et al., 1994), and potassium channels (Chung et al., 1995).

The hypothesis for a central inhibition to $\mathrm{LHRH}$ release before the onset of puberty has been proposed for some time. Gonadotropin levels of children with agonadal syndrome are very low, and gonadotropins do not increase until the age of puberty (Winter and Faiman, 1972; Conte et al., 1975). The release of $\mathrm{LHRH}$ and gonadotropins is not altered by gonadectomy until the onset of puberty in monkeys (Plant, 1983; Terasawa et al., 1983; Wilson et al., 1986; Chongthammakun et al., 1993). Frecocious puberty has been observed in children with brain tumors and brain injury (Bauer, 1959; Byrnes et al., 1974) as well as in female rhesus monkeys with lesions in the posterior portion of the hypothalamus (Terasawa et al., 1984; 
A

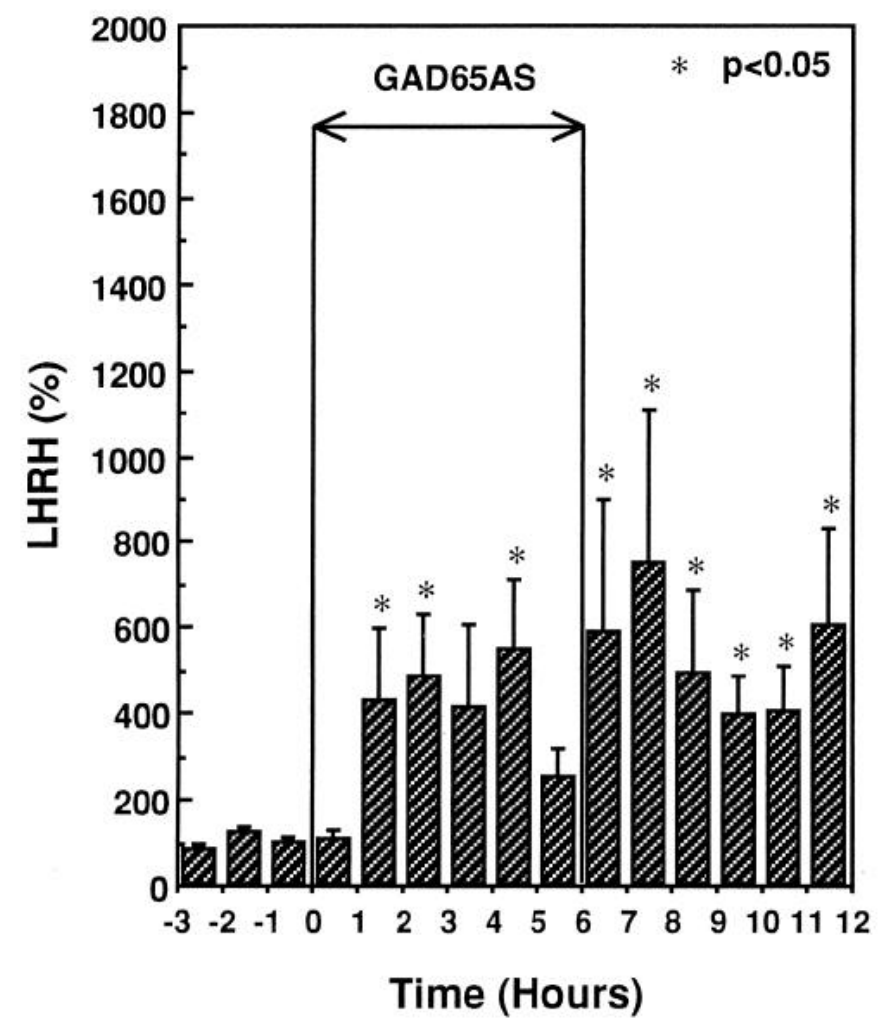

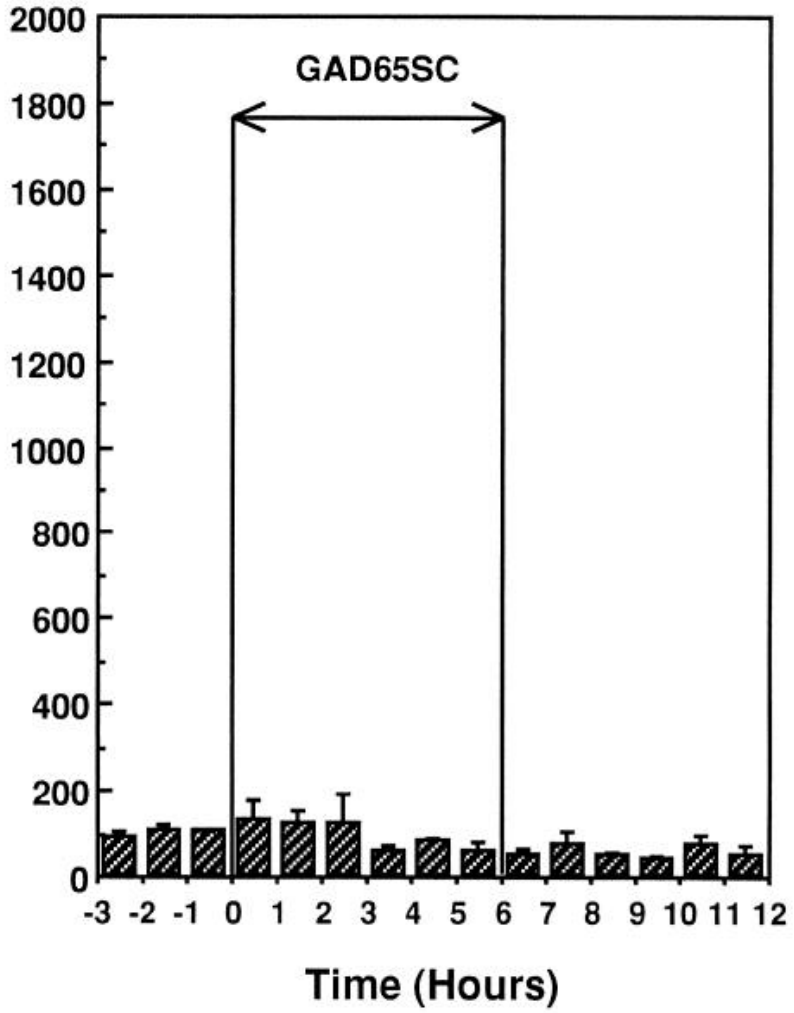

Time (Hours)

Figure 8. Effects of GAD65AS $(A)$ or GAD65SC $(B)$ on mean LHRH release in prepubertal monkeys. Mean LHRH release was calculated for each 60 min period. Data were analyzed using ANOVA with repeated measures followed by Student-Newman-Keuls multiple-range test (mean \pm SEM, $n=4$ in $G A D 65 A S, n=6$ in $G A D 65 S C$; $\left.{ }^{*} p<0.05\right)$. Overall significance between the treatments was $p<0.01$.

Schultz and Terasawa, 1988). Nevertheless, little evidence is available for the neural substrate responsible for the central inhibition before the onset of puberty.

Previously, we reported that a decrease in GABA release and a concomitant increase in LHRH release occurred in the S-ME of prepubertal monkeys (Mitsushima et al., 1994), and the infusion of bicuculline into the S-ME in prepubertal monkeys stimulated LHRH release drastically, whereas bicuculline infusion in pubertal monkeys stimulated LHRH release very little (Mitsushima et al., 1994). Based on these observations, we proposed a hypothesis that GABA is a neurotransmitter restricting LHRH release before the onset of puberty. The present study further examines this hypothesis by interfering with GAD synthesis using the antisense D-oligos for GAD mRNAs. The treatment with both antisense D-oligos for GAD67 and GAD65 mRNAs resulted in an increase in LHRH release in prepubertal monkeys, although the response to the antisense GAD65 was smaller than that seen for the antisense GAD67. Because the antisense D-oligos decrease GAD expression examined by Western blot analysis, and because GABA release decreases after exposure to the antisense D-oligos (E. Terasawa, unpublished data), we can speculate that infusion of the antisense GADs may cause the reduction of GABA, which in turn results in the increase in LHRH release. These results are consistent with our hypothesis.

In this study, whereas infusion of antisense D-oligos resulted

GAD65 GAD67

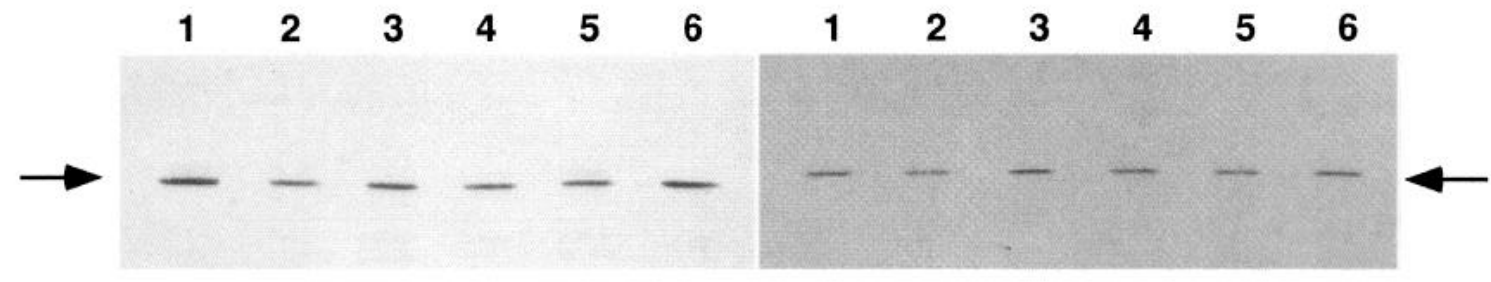

Figure 9. Specificity of the antisense D-oligos for GAD mRNAs. Expressions of GAD65 (left) and GAD67 (right) examined by the Western blotting analysis are shown. Lanes are labeled as follows: hypothalamus exposed to scrambled (1) and to antisense (2) D-oligos; cerebellum exposed to scrambled (3), to antisense (4), and to sense (5) D-oligos; and cerebellum not exposed to any D-oligo (6). Arrows indicate the migration of $66 \mathrm{kDa}$ molecular weight marker (bovine serum albumin). 
in a large response of LHRH release (Figs. 3, 5, 6, 8), incubation of hypothalamic and cerebellar tissues with antisense D-oligos only decreased GAD expression by a small amount (Fig. 9). Furthermore, the effects of GAD antisense infusion into the $\mathrm{S}-\mathrm{ME}$ on $\mathrm{LHRH}$ release in this study were much greater than those of $\mathrm{GABA}_{\mathrm{A}}$ receptor antagonist infusion examined with the same method (Mitsushima et al., 1994). These observations raise two questions. (1) Is GAD reduction linear to GABA reduction? (2) Can the increase in LHRH release by antisense D-oligos be solely attributed to GABA reduction? There are at least three possible explanations for these questions. First, because excessive amounts of GADs are present in GABA neurons (Martin and Rimvall, 1993), only a small decrease in GADs may be sufficient for the reduction of GABA release, rcsulting in an increase in LHRH release. Second, the effects seen with GAD antisense infusion may be partly attributable to an extracellular increase in glutamate, which has been shown to be a stimulatory neurotransmitter for LHRH release in prepubertal animals (Claypool and Terasawa, 1989; Plant et al., 1989; Urbanski et al., 1990; Bourguignon et al., 1992; Nyberg et al., 1995). The reduction of GADs by the antisense D-oligos could result in the intracellular accumulation of glutamate, which might be transported out to the extracellular space by glutamate transporters where it can act as an excitatory neurotransmitter. It has been shown that glutamate transporters can play a role in transporting the amino acid in both directions (Kanai et al., 1993), and there is the possibility of metabolic glutamate release induced by reversed uptake, described as nonvesicular release (Szatkowski et al., 1990; Attwell et al., 1993). This speculation is not totally unfounded, because a recent report using immunocytochemis try indicated that some GAD-positive neurons in the mediobasal hypothalamus were also glutamate-positive in monkeys (Thind and Goldsmith, 1993). Moreover, our preliminary data measuring glutamate in samples from an in vivo push-pull perfusion study suggest that glutamate increases during exposure to the antisense GAD67. Third, because inhibition of GAD synthesis may facilitate other less dominant synthetic pathways for GABA, such as formation from putrescine or $\gamma$-hydroxybutyrate, the GAD reduction may not be linear to the GABA reduction. Further studies are necessary to pursue these issues.

There appears to be a two-step process for the mechanism of puberty. First, disinhibition of LHRH neurons from GABA may trigger the onset of puberty. A concurrent excitatory input from glutamate may also be very important at this time, as discussed carlier. Second, the contribution from norepinephrine and NPY neurons is important for the further pubertal increase in LHRH release and, hence, the additional progress of puberty, as we reported previously (Gore and Terasawa, 1991; Gore et al., 1993).

In conclusion, interference of GAD synthesis with antisense D-oligos for GAD mRNAs induced a prompt and large increase in LHRH release in prepubertal monkeys. The results not only support our hypothesis that GABA is an inhibitory neurotransmitter restricting $\mathrm{LHRH}$ release before the onset of puberty, but also lead to the concept that maturational changes in GAD synthesis may be important for the onset of puberty in primates.

\section{REFERENCES}

Attwell D, Barbour B, Szatkowski M (1993) Nonvesicular release of neurotransmitter: a review. Neuron 11:401-407.
Bauer MG (1959) Endocrine and metabolic condition related to pathology in the hypothalamus: a review. J Nervous Mental Dis 128:323-338.

Benson DL, Isackson PJ, Hendry SHC, Jones EG (1991) Differential gene expression for glutamic acid decarboxylase and type II calciumcalmodulin-dependent protein kinase in basal ganglia, thalamus, and hypothalamus of the monkey. J Neurosci 11:1540-1564.

Bourguignon JP, Gcrard A, Alvarcz-Gonzalcz M, Fawc L, Franchimont P (1992) Gonadal-independent developmental changes in activation of $\mathrm{N}$-methyl-D-aspartate receptors involved in gonadotropin-releasing hormone secretion. Neuroendocrinology 55:634-641.

Byrnes ND, Clautier MD, Hayles AB (1974) The central nervous system and precocious puberty. In: The control of the onset of puberty (Grumbach MM, Grave GD, Mayer FE, eds), pp 213-228. New York: Wiley.

Bu DF, Erlander MG, Hintz BC, Tillakaratne NJ, Kaufman DL, WagnerMcPherson CB, Evans GA, Tobin AJ (1992) Two human glutamate decarboxylases, $65 \mathrm{kDa}$ GAD and $67 \mathrm{kDa} \mathrm{GAD}$, are each encoded by a single gene. Proc Natl Acad Sci USA 89:2115-2119.

Chongthammakun S, Claypool LE, Terasawa E (1993) Ovariectomy increases in vivo LHRH release in pubertal, but not prepubertal, female rhesus monkeys. J Neuroendocrinol 5:41-50.

Chung S, Saal DB, Kaczmarek LK (1995) Elimination of polassium channel expression by antisense oligonucleotides in a pituitary cell line. Proc Natl Acad Sci USA 92:5955-5959.

Claypool LE, Terasawa E (1989) $N$-methyl-D,L-aspartate (NMDA) induces LHRH release as measured by in vivo push-pull perfusion in the stalk-median eminence of pre- and peripubertal female monkeys. Biol Reprod 40[Suppl 1]:83.

Claypool LE, Watanabe G, Terasawa E (1990) Effects of electrical stimulation of medial basal hypothalamus on the in vivo release of luteinizing hormone-releasing hormone in the prepubertal and peripubertal monkey. Endocrinology 127:3014-3022.

Conte FA, Grumbach MM, Kaplan SL (1975) A diphasic pattern of gonadotropin secretion in patients with the syndrome of gonadal dysgenesis. J Clin Endocrinol Metab 40:670-675.

Christgau S, Schierbeck H, Aanstoot H-J, Aagaard L, Begley K, Kofod H, Hejnaes K, Baekkeskov S (1991) Pancreatic $\beta$ cells express two autoantigenic forms of glutamic acid decarboxylase, a $65 \mathrm{kDa}$ hydrophilic form and a $64 \mathrm{kDa}$ amphiphilic form which can be both membranebound and soluble. J Biol Chem 266:21257-21264.

Fsclapez M, Tillakaratne N.JK, Kaufman DI, Tobin A.J, Houser CR (1994) Comparative localization of two forms of glutamic acid decarboxylase and their mRNAs in rat brain supports the concept of functional differences between the forms. J Ncurosci 14:1834-1855.

Gearing M, Terasawa E (1988) Luteinizing hormone-releasing hormone (LHRH) neuroterminals mapped using the push-pull perfusion method in the rhesus monkey. Brain Res Bull 21:117-121.

Goldsmith PC, Song T (1987) The gonadotropin-releasing hormone containing ventral hypothalamic tract in the fetal rhesus monkey (Macaca mulatta). J Comp Physiol 257:130-139.

Golos TG, Durning M, Fisher JM, Fowler PD (1993) Cloning of four growth hormone/chorionic somatomammotropin-related complementary deoxyribonucleic acids differentially expressed during pregnancy in the rhesus monkey placenta. Endocrinology 133:1744-1752.

Gore AC, Terasawa E (1991) A role for norepinephrine in the control of puberty in the female rhesus monkey, Macaca mulatta. Endocrinology 129:3009-3017.

Gore AC, Mitsushima D, Terasawa E (1993) A possible role of neuropeptide- $Y$ in the control of the onset of puberty in female rhesus monkeys. Neuroendocrinology 58:23-34.

Grumbach MM, Kaplan SL (1990) The neuroendocrinology of human puberty: an ontogenetic perspective. In: Control of the onset of puberty (Grumbach MM, Sizonenko PC, Aubert ML, eds), pp 1-48. Baltimore: Williams \& Wilkins.

Helene C, Toulme J (1990) Specific regulation of gene expression by antisense, sense and antigene nucleic acids. Biochim Biophys Acta 1049:99-125.

Kanai Y, Smith CP, Hediger MA (1993) The elusive transporters with a high affinity for glutamate. Trends Neurosci 16:365-370.

Karlsen AE, Hagopian WA, Grubin CE, Dube S, Disteche CM, Adler DA, Bärmeier H, Mathewes S, Grant FJ, Foster D, Lernmark A (1991) Cloning and primary structure of a human islet isoform of glutamic acid decarboxylase from chromosome 10. Proc Natl Acad Sci USA 88:8337-8341.

Kregenow D, Ratajczak MZ, Gewirtz AM (1995) Disrupting the flow of genetic information with antisense oligodeoxynucleotides: research and 
therapeutic applications. In: Delivery strategies for antisense oligonucleotide therapeutics (Akhtar S, ed), pp 1-15. Boca Raton, FL: CRC.

Legrand GC, Ramirez JJ, Shih Y-H, Smith T, Greenwood RS, Hayward JN, Meeker RB (1993) Antisense vasopressin oligonucleotides: hypothalamic uptake, turnover and effects on fluid intake. Soc Neurosci Abstr 19:44.

Loke SL, Stein CA, Zhang XH, Mori K, Nakanishi M, Subasinghe C, Cohen JS, Neckers LM (1989) Characterization of oligonucleotide transport into living cells. Proc Natl Acad Sci USA 86:3474-3478.

Martin DL, Rimvall K (1993) Regulation of $\gamma$-aminobutyric acid synthesis in the brain. J Neurochem 60:395-407.

McCarthy MM, Schlenker EH, Pfaff DW (1993) Enduring consequences of neonatal treatment with antisense oligodeoxynucleotides to estrogen receptor messenger ribonucleic acid on scxual differentiation of rat brain. Endocrinology 133:433-439.

McCarthy MM, Masters DB, Rimvall K, Schwartz-Giblin S, Pfaff DW (1994) Intracerebral administration of antisense oligodeoxynucleotides to GAD65 and GAD67 mRNAs modulate reproductive behavior in the female rat. Brain Res 636:209-220.

Michelsen BK, Petersen JS, Boel E, Møldrup A, Dyrberg T, Madsen OD (1991) Cloning, characterization, and autoimmune recognition of rat islet glutamic acid decarboxylase in insulin-dependent diabetes mellitus. Proc Natl Acad Sci USA 88:8754-8758.

Mitsushima D, Hei DL, Terasawa E (1994) $\gamma$-Aminobutyric acid is an inhibitory neurotransmitter restricting the release of luteinizing hormonereleasing hormone before the onset of puberty. Proc Natl Acad Sci USA 91:395-399.

Nyberg CN, Srivastrava VN, IIiney JK, Dees WL (1995) N-methyl-DLaspartic acid receptor messenger ribonucleic acid levels and luteinizing hormone release in immature female rats: effects of stage of pubertal development and exposure to ethanol. Endocrinology 136:2874-2880.

Ogawa S, Olazábal UE, Parhar IS, Pfaff DW (1994) Effect of intrahypothalamic administration of antisense DNA for progesterone receptor mRNA on reproductive behavior and progesterone receptor immunoreactivity in female rats. $J$ Neurosci 4:1766-1774.

Plant TM (1983) Ontogeny of gonadotropin secretion in the rhesus macaque (Macaca mulatta). In: Neuroendocrine aspects of reproduction (Norman RL, ed), pp 133-147. New York, Academic.

Plant TM (1988) Puberty in primates. In: The physiology of reproduction (Knobil E, Neill J, eds), pp 1763-1787. New York: Raven.

Plant TM, Gay VL, Marshall GR, Anslan M (1989) Puberty in monkeys is triggered by chemical stimulation of the hypothalamus. Proc Natl Acad Sci USA 86:2506-2510.

Rasmussen DD, Kennedy BP, Ziegler MG, Nett TM (1988) Endogenous opioid inhibition and facilitation of gonadotropin-releasing hormone release from the median eminence in vitro: potential role of catecholamines. Endocrinology 123:2616-2621.

Rimvall K, Martin DL (1994) The level of GAD67 protein is highly sensitive to small increases in intraneuronal $\gamma$-aminobutyric acid level. J Neurochem 62:1375-1381.

Ronnekleiv OK, Resko JA (1990) Ontogeny of GnRH-containing neurons in early fetal development of rhesus macaques. Endocrinology 126:498-511.

Schultz NJ, Terasawa E (1988) Posterior hypothalamic lesions advance the time of the pubertal changes in luteinizing hormone release in ovariectomized female rhesus monkeys. Endocrinology 123:445-455.
Silverman A-J, Antunes JL, Abrams GM, Nilaver G, Thau R, Robinson JA, Ferin M, Krey LC (1982) The luteinizing hormone-releasing hormone pathways in rhesus (Macaca mulatta) and pigtailed (Macaca nemestrina) monkeys: new observations on thick, unembedded sections. J Comp Neurol 211:309-317.

Szatkowski M, Barbour B Attwell D (1990) Non-vesicular release of glutamate from glial cells by reversed electrogenic glutamate uptake. Nature 348:443-446.

Terasawa E (1994) In vivo measurement of pulsatile release of neuropeptides and neurotransmitters in rhesus monkeys using push-pull perfusion. In: Methods in neuroscience: pulsatility in neuroendocrine systems (Levine JE, ed), pp 184-202. New York: Academic.

Terasawa E (1995) Mechanisms controlling the onset of puberty in primates: the role of GABAergic neurons. In: The neurobiology of puberty (Plant TM, Lee PA, eds), pp 139-151. Bristol: J Endocrinol Ltd.

Terasawa E, Claypool L, Watanabe G, Gore A (1990) The timing of the onset of puberty in the female rhesus monkey. In: Control of the onset of puberty, Pt II (Delemarre-Van de Waal HA, Plant TM, van Rees GP, Shoemaker J, eds), pp 123-136. Ansterdani: Elsevier.

Terasawa E, Nass TE, Yeoman RR, Loose MD, Shultz NJ (1983) Hypothalamic control of puberty in the female rhesus macaque. In: Neuroendocrine aspects of reproduction (Norman RL, ed), pp 149-182. New York: Academic.

Terasawa E, Noonan JJ, Nass TE, Loose MD (1984) Posterior hypothalamic lesions advance the onset of puberty in the female rhesus monkey. Endocrinology 115:2241-2250.

Thind KK, Goldsmith PC (1993) Glutamate and GABA neurons interact extensively in neuroendocrine regions of the female monkey brain. Soc Neurosci Abstr 19:570.

Urbanski HF, Ojeda SR (1990) A role for $N$-methyl-D-aspartate (NMDA) receptors in the control of $\mathrm{LH}$ secretion and initiation of female puberty. Endocrinology 126:1774-1776.

Vician L, Adams LA, Clifton DK, Steiner RA (1991) Pubertal changes in proopiomelanocortin and gonadotropin-releasing hormone gene expression in the brain of the male monkey. Mol Cell Neurosci 2:31-38.

Wahlestedt C, Pich EM, Koob GF, Yee F, Heilig M (1993) Modulation of anxiety and neuropeptide Y-Y1 receptors by antisense oligodeoxynucleotides. Science 259:528-531.

Walder RY, Walder JA (1988) Role of RNase H in hybrid-arrested translation by antisense oligonucleotides. Proc Natl Acad Sci USA 85:5011-5015.

Watanabe G, Terasawa E (1989) In vivo release of luteinizing hormone releasing hormone increases with puberty in the female rhesus monkey. Endocrinology 125:92-99.

West AP, Cooke BA (1991) A novel method to modulate desensitization and truncation of luteinizing hormone receptors using antisense oligodeoxynucleotides. Mol Cell Endocrinol 79:R9-R14.

Wilson ME, Gordon TP, Collins AC (1986) Ontogeny of luteinizing hormone secretion and first ovulation in seasonal breeding rhesus monkeys. Endocrinology 118:293-301.

Winter JSD, Faiman C (1972) Serum gonadotropin concentrations in agonadal children and adults. J Clin Endocrinol Metab 35:561-564.

Woolfe TM, Melton DA, Jennings GB (1992) Specificity of antisense oligonucleotides in vivo. Proc Natl Acad Sci USA 89:7305-7309. 